\title{
Characterization of glucagon-like peptide-I(7-36)amide receptors of rat lung membranes by covalent cross-linking
}

\author{
Gerd Richter', Rüdiger Göke', Burkhard Göke', Harald Schmidt' and Rudolf Arnold'

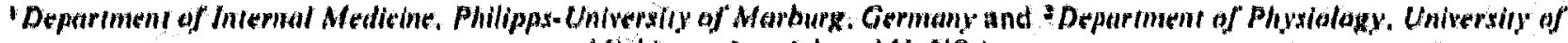 \\ Michigain, Anm Arbor. MII, USA
}

Reeeived 16 January 1991

\begin{abstract}
14 Trabelled GLP.I(7.36)amide wax eross-linked to a specific binding protein in rat lung membranes using dixuceininidyl suberate. A single radio. labelled band at $M, 66000$ wax identilled by SDS-PAGE after solubilization of the ligand-bindins protein eomplex which ix eansixtem with the presence of a single elass of binding sites on rat lung membranes. The band was undelectable when I $\mu$ mol// GLP.I(7 36$)$ amide was ineluded in the binding assay. No change in the mobility of the bund wax observed under redueing conditions suggesting that the binding protein in the receptor

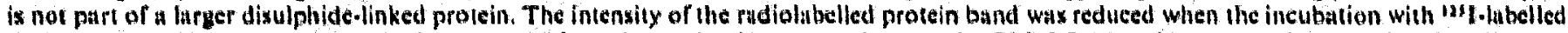
GLP-I(7.36)amide was carried out in the presenec of guanine nueleotides sugenting thar the GLP.I(7 36)amide receptor is eoupled to the adenylate eyclase syutem.
\end{abstract}

GLP.I(7-36)amide; Receptor: Lung: Covalent eross-linking

\section{INTRODUCTION}

Glucagon-like peptide-1(7-36)amide (GLP-1) is a posttranslational processing product of proglucagon in the mammalian intestine [1-3]. The amino acid sequence of GLP-1 was kept during evolution and is identical in different mammals including man [4-6]. This in. dicates an important biological meaning of GLP.I at least in manmals. In previous studies, it has been shown that GLP-1 is released in response to oral glucose and potently stimulates the glucose-induced insulin secretion [7-9]. Thus, GLP.1 is considered to be a new incretin candidate besides the gastric inhibitory peptide (GIP). Furthermore, GLP-1 is a strong inhibitor of the pentagastrin-stimulated gastric acid secretion and therefore considered to be an enterogastrone candidate $[10,11]$. Corresponding to these data, receptors for GLP-1 have been identified on rat insulinoma-derived RINmSF cells and isolated gastric glands of the rat $[12,13]$. Recently, we demonstrated specific binding sites for GLP-1(7-36) amide on rat lung membranes [14]. The present study describes the use of a covalent cross-linking reagent to further characterize the ligandbinding component of the GLP-1 receptor on rat lung membranes.

Correspondence address: G. Richter, Zentrum Innere Medizin, Klinikum der Philipps-Universitä, Baldinger Straße, D-3550 Marburg, Germany

\section{MATERIALS AND METHODS}

\subsection{Reagents}

GLP-I(7-36)anide was purehased from Peninsula Laboratories (St. Helens, Merseyside, UK). Disuccinimidyl suberate was from Pieree Europe BV (Oud-Beijerland, The Netherlands). GTP.y-S and GDP-3.S were from Sigma Chemicals (Deisenhofen, Germany). 12\%1labelled CLP.1(7-36) anvide (spec, aet. $74 \mathrm{TBq} / \mathrm{mm}$ ol) was prepared as described by Güke and Conlon [12].

\subsection{Cells}

RINinSF cells were grown in plastic culture bollles under the condi. tions described by Priz et al. [15]. The cells were detached from the surface of the bottles before experimentation using phosphate: buffered saline $\left(\mathrm{NaCl} 136 \mathrm{mmol} / \mathrm{KCl} 2.7 \mathrm{mmol} / \mathrm{K}, \mathrm{Na}_{2} \mathrm{HPO}, 8.1\right.$ mmol/l, $\left.\mathrm{KH}_{2} \mathrm{PO}_{4} 1.5 \mathrm{mmol} / \mathrm{l} \mathrm{pH} 7.3\right)$ containing $0.7 \mathrm{mmol} / \mathrm{EDTA}$. Cell concentrations were detcrmined either by using a Neubauer hacmosytometer or by nieasurement of cellular DNA [16].

\subsection{Membrane preparalion}

Plasma membrancs of RINm5F cells were prepared as described previously [17]. Bricfly, approximately $6 \times 10^{R}$ RINm5F cells were suspended in $30 \mathrm{ml}$ ice-cold homogenization buffer (Tris. $\mathrm{HCl} 10$ $\mathrm{mmol} / \mathrm{l}, \mathrm{NaCl} 30 \mathrm{mmol} / \mathrm{l}$, dithothreitol $1 \mathrm{mmol} / \mathrm{l}$, phenylmethylsulphonylfluoride (PMSF) $5 \mu \mathrm{mol} / \mathrm{i} ; \mathrm{pH} 7.5$ ) and disrupted using a tight-fitting glass-glass homogenizer with six passages at $150 \mathrm{rpm}$.

Rat lung membranes were prepared as described in detail previously [14]. Male albino Wistar rats $(200-220 \mathrm{~g}$ body weight) were killed by decapitation, the lungs were removed and homogenized in homogenization buffer with an Ultra-Turrax followed by a further homogenization using a glass-glass homogenizer.

The following steps in the preparation of $\mathrm{RINm} S \mathrm{~F}$ cell plasma membranes and rat lung membranes were identical. The homogenate was layered over a $41 \%(\mathrm{w} / \mathrm{v})$ sucrose solution and centrifuged for 60 min at $4^{\circ}$ at $95000 \times 8$. The band at the interface of the layers represented the membranes and was collected, diluted and centrifuged for $30 \mathrm{~min}$ at $40000 \times \mathrm{g}$. The pellet was resuspended in a modified Krebs-Ringer buffer (KRB) (Tris- $\mathrm{HCl} 2.5 \mathrm{mrno} / \mathrm{l}, \mathrm{NaCl} 120 \mathrm{mmol} / \mathrm{l}$, 


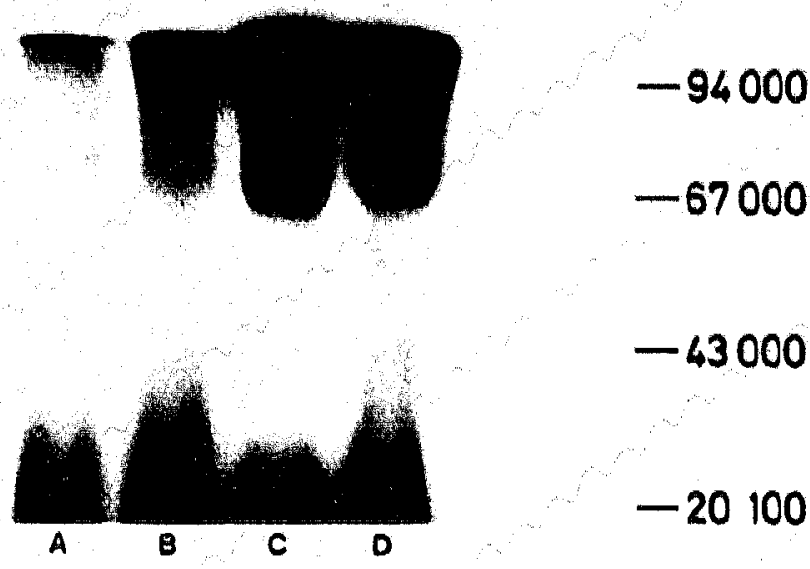

Fig. I Errect or ylucuson-like peptide-1(7-36)amide (GL.P.1(7-36).

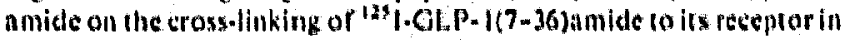
rat lung plasma membranes. Equal aliquors of membranes were incubated with iracer in the absence (D) and presenee of 0.1 nmol 1 (C). $10 \mathrm{nmal} / \mathrm{B}$ (B) and $1000 \mathrm{nmol} / \mathrm{A}$ (A) GLP.1(7-36)amide. Experiment was carried oul as deseribed in section 2. The numbers show the mobilitics of phosphorylase $b(M, 94000)$, human serum albumin $(M, 67000)$, ovalbumin $(M, 43000)$ and trypsin inlibitor $(M$, $20100)$.

MgsO, 1.2 mmol/l, $\mathrm{KCl} 5 \mathrm{mmol} / \mathrm{l}, \mathrm{CH}, \mathrm{COONa}$ (s mnol//; $\mathrm{PH} 7.4$ ) containing $1 \%(w / v)$ human serum albumin, $0.1 \%$ (w/v) bacitracin and EDTA I mmol/l, frozen in liquid nilrogen and stored at $-80^{\circ} \mathrm{C}$. Protein concentration was determined as deseribed by Bradford [18].

\subsection{Cross.linking experiments}

Plasma membranes $(200 \mu \mathrm{g})$ were incubated with $12 /$-labelled GLP.1(7-36)anide (approximately $40000 \mathrm{epm}$ spec. act. approx. 74 $\mathrm{TBq} / \mathrm{mmol}$ ) in Hepes buffer ( $50 \mathrm{mmol} / \mathrm{pH}, 7.5$ ) containing $0.02 \%$ (w/v) human serum albumin for $30 \mathrm{~min}$ at $37^{\circ} \mathrm{C}$. Incubations were also carried out in the presence of a range of concentrations of unlabelled GLP-1(7-36)amide or in the presence of guanine nucleotides as indicated. Ineubations wepe terminated by centrifugation $\left(10000 \times g\right.$ for $5 \mathrm{~min}$ at $\left.4^{\circ} \mathrm{C}\right)$ and pelless resuspended in ice-cold Hepes buffer (10 mmol/1; pH 9.0$)$ containing $0.02 \%$ (w/v) liuman serum albumin.

A solution of disuccinimidy! suberate in dimethylsulphoxide was added to give a $0.1 \mathrm{mM}$ final concentration [17]. After incubation for $10 \mathrm{~min}$ at $4^{\circ} \mathrm{C}$ the reaction was stopped by addition of ammonium acetate solution (final concentration $10 \mathrm{mmol} / \mathrm{l}$ ). Membranes were centrifuged $\left(10000 \times \mathrm{g}\right.$ for $5 \mathrm{~min}$ at $\left.4^{\circ} \mathrm{C}\right)$ and the pellets resuspended in Hepes buffer $(10 \mathrm{mmol} / 1$; $\mathrm{pH} 7.5)$ colltaining $0.02 \%$ human serum albumin. An incubation for $30 \mathrm{~min}$ at $25^{\circ} \mathrm{C}$ was carried out in order to dissociate non-covalently bound ligand. After centrifugation $\left(10000 \times \mathrm{g}\right.$ for $5 \mathrm{~min}$ at $\left.4^{\circ} \mathrm{C}\right)$, the pellets were suspended in sodium phosphate buffer $(10 \mathrm{mmol} / \mathrm{l} ; \mathrm{pH} 7.5)$ containing $2 \%(\mathrm{w} / \mathrm{v})$ sodium dodecylsulphate (SDS). Samples were boiled for $5 \mathrm{~min}$ in the presence and absence of $5 \%(\mathrm{v} / \mathrm{v})$ mercaptoethanol. Electrophoresis was carried out using the discontinuous buffer system described by Laeminli [19] with a $4 \%$ acrylamide stacking gel and a $10 \%$ acrylamide separating gel. The gels were calibrated using a molecular weight marker kit from Pharmacia, Uppsala, Sweden. Gels were dried and exposed to Kodak type X-Omat AR film for 2 weeks at $-80^{\circ} \mathrm{C}$ using an image-iatensifying screen.

\section{RESULTS}

Incubation of lung membranes with ${ }^{125}$ I-labelled GLP-1(7-36)amide followed by chemical cross-linking and solubilization has identified a single ligand-binding protein complex of $M_{r} 66000 \pm 1000(n=6)$ (Fig. 1). The intensity of the radiolabelled band was reduced when the incubation with ${ }^{125}$ I-labelled GLP-1(7-36) amide was carried out in the presence of increasing concentrations of unlabelled GLP.1(7-36)amide. At 1 $\mu \mathrm{mol} / \mathrm{l}$ unlabelled GLP-1(7-36)amide no band was detectable anymore (Fig. 1). When experiments were carried out in the absence of rat lung membranes no radioactive labelled band was detectable in the gel. Incubations carried out in the presence of GTP- $\gamma-S(0.1$ $\mathrm{mmol} / \mathrm{l})$ or GDP- $\beta-\mathrm{S}(0.1 \mathrm{mmol} / \mathrm{l})$ resulted in a reduction of the specific receptor linked tracer binding (Fig. 2).

A solubilization of the cross-linked receptor/ligand complex under reducing conditions did not lead to a change of the motility of the labelled $M_{\mathrm{r}} 66000$ band (Fig. 3).

Previously, we characterized GLP-1 receptors on RINm5F plasma membranes by covalent cross-linking [17]. Experiments carried out to compare cross-linked and solubilized GLP-1 receptor-ligand complexes from rat lung and RINm5F membranes revealed no significant difference in the molecular weight of the ligandbinding protein complexes (Fig. 4).

Vasoactive intestinal peptide (VIP) and peptide histidine isoleucine (PHI) are able to displace ${ }^{125} \mathrm{I}-$ GLP-1(7-36)amide from rat lung membranes with a $K_{\mathrm{d}}$ 

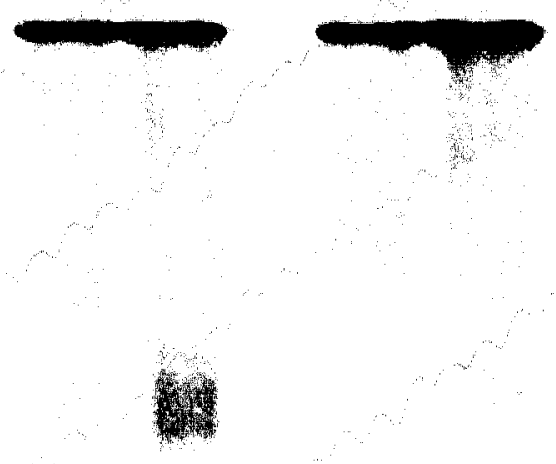

$-94000$

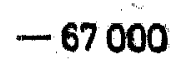

$-43000$

A

B

C D

Fiz. 3. Erreer of solubilization under redueing condinions on the eross. linking of 1"'-GLP.1(7-36)amicte to is receptor in rat lung plasma membranes. Solubilization was earred out in the presence $(A, B)$ and absence $(C, D)$ of $50(\mathrm{~V} / \mathrm{N})$ ismereaptocthanol. Incubations were carried out in the absence (B,D) and presenee $(A, C)$ of $1 \mu$ mol/ GLP-1(7-36)amide. The numbers show the mobilities of phosphorylase $b(M, 94000)$, human serum albumin $(M, 67000)$ and ovalbunin $(M, 43000)$.

which is 2.5 and 4.7 times less, respectively, than that of GLP-1(7-36)amide [14]. We then incubated rat lung membrancs (1 $\mathrm{mg}$ protein/ml) with ${ }^{125} \mathrm{I}-\mathrm{VLP}$ in the presence and absence of GLP-1(7-36)amide. GLP-1(7-36)amide did not displace ${ }^{125}$ I.VIP from its binding to rat lung membranes (data not shown).

\section{DISCUSSION}

Recently, we demonstrated the presence of a single class of high affinity receptors for GLP-1(7-36)amide on rat lung membranes [14]. Consistent with this result only a single protein with $M_{\mathrm{r}} 66000$ was affinitylabelled using the cross-linking agent disuccinimidyl suberate which is reactive towards amino groups and has found widespread application in the characterization of binding proteins for neurohormonal peptides [20-25]. Evidence that the tracer bound to a component of the GLP-1 receptor was obtained by the fact that labelling of the protein was inhibited by increasing concentrations of unlabelled GLP-1(7-36)amide.

Solubilization of the receptor/ligand complex under reducing conditions did not lead to a change of the motility of the labelled band suggesting that the binding component for GLP-1(7-36)amide in rat lung membranes is not a part of a larger disulphide-linked protein.
Recently, we reported that binding of $125 \mathrm{I}$ GLP-1(7-36)amide to lung membranes is decreased in the presence of guanine nucleotides [14]. Confirming these data, we demonstrate now that incubations in the presence of guanine nucleotides resulted in a reduction of the specific receptor linked tracer binding. This supports the assumption that in rat lung membranes GLP-1 (7-36)amide receptors are also linked to the adenylate cyclase system.

The data of this study are very similar to results we obtained with GLP-1(7-36)amide receptors from RINm5F plasma membranes in a previous study [17]. Directly compared both receptors exhibited the same molecular weight. Thus, it seems that GLP-1(7-36)amide receptors in RINmSF and rat lung plasma membranes do not differ due to their biochemical properties.

Interestingly, the binding affinity of GLP-1(7-36)amide on rat lung receptors is 10 times less compared to receptors on RINmSF membranes [14]. Furthermore, vasoactive intestinal peptide (VIP) and peptide histidine isoleucin (PHI) do not bind to GLP-1(7-36)amide receptors on RINm5F membranes but are able to dispiace ${ }^{125}$ I-GLP-1(7-36)amide from rat lung membranes with a $K_{\mathrm{d}}$ which is only 2.5 and $4 . \overline{7}$ times, respectively, less than that of GLP-1(7-36)amide [14] while ${ }^{125}$ I-VIP is not displaced by GLP-1(7-36)amide from rat lung membranes. 


\section{REFERENCES}

(I) Hell, G.1., Samerre, R.F, and Mullenbaeh, (1,T. (IDS3) Nalure 102. $710-710$

13) Holu, J.J., Onkew, C., Van Niclien, O. and Sehwarld, T.W. (1987) PEBS Le11, 211, 169)=174.

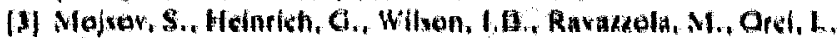
and HabencF, J.F. (1986) J. Bial, Chem, 261, 11880-11889.

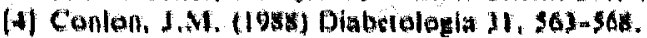

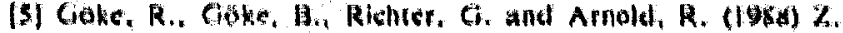
Gaviroenterologie 36, 7Is-71\%.

(6) Seino, S., Welkh, M., Bell, G.J., Cham, S.J. and Steiner, D.F. (1986) FEDS L.e11. 203, 23-30,

(2) Drusker, D.J., Philippe. J., Mojrar, S.. Setick, W, $c$ and Habener, J.F, (1987) Proe. Nail. Aewd. Sti, USA 84, 341443438.

[8] Holsi, J.J., Orskov, C., Nielsen O.V. and Sillwarlo, T.W. (1987) FEBS 1.e11. 211, 160-174.

(9) Mojror, S., Weir, G. and Habener, J.t. (19/7) J, Clin, Inven, $79,616-01 \%$.

(lo) Schjoldager, B.f.G., Mortensen. P.E., Chrisiansen, J., Orsker, C. and Holsi, J.J. (1989) Dig. Dis. Sel, 34, 703.708.

(1) Hansen, A.B., Gespach, C.P., Rosselin, C.E. and Hols, J.d. (1988) FEBS LeII, 236, 119-122.

(12) Góke, R, and Conlon, J.M. (1988) J. Endocrinal, 110, 397-362.

(i3) Uitemilal, L.O. and Bikzquey E. (1990) FEBS Let? 267, $139-141$

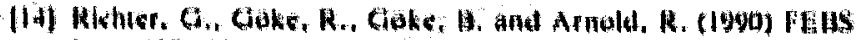
L.811. 26\%, 76s

(1) Pra, G.A., Halban. P.A. Wollheim. C.A., Blondel, A.,

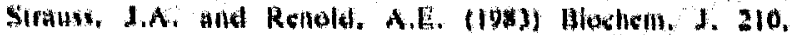
$145=35$.

(16) Burnoti. K. (1958) Hiochem. J. A2, 113.311.

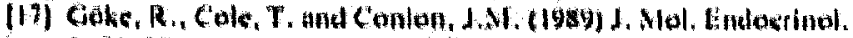
2. 91-0.8.

(17) Bradtord, M. (1976) Anal. Biathem. 72, 248-244.

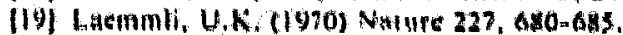

(20) Krit, K., Hazan, R, Villinos, J., Moody, T.W. wasl Sellasinger, J. (19\%7) d. Biol. Chem, 262.11213=11220.

(21) Fuard, S.M. and Crait, R.K. (1987) Eur, d. Bioshem, 170. $373-379$,

(22) Vandlen, R.L., Areuri, K. E. and Napier, N.A. (1985) J. Bial. Chem, 260, 10\$89-10842

(23) Pestson, R.K. and Miller, L.J. (1987) d, Biol, Ghem, 202. $869-876$

(2.) Pileh, P.P. and Cech, W.P. (1979) J, Biol. Chem, 234, $3,375-3381$.

(25) Laburthe. M.. Brean, B. and Pouyer-Fessard, C. (1984) Eur. J. Biachem, 139, 181=187. 